Bangladesh J. Zool. 42(2): 169-181, 2014

\title{
BREEDING BIOLOGY OF BENGAL EYED TURTLE MORENIA PETERSI (ANDERSON 1879) IN BANGLADESH
}

\author{
Md. Lokman Hossain ${ }^{1}$, Shorab Uddin Sarker and Noor Jahan Sarker \\ Department of Zoology, University of Dhaka, Dhaka-1000, Bangladesh
}

\begin{abstract}
This study was conducted to determine the breeding season, gonad development, egg laying period, clutch size and other biological aspects of Bengal Eyed Turtle, Morenia petersi of Bangladesh. The egg-laying period was found between November and February. The nesting sites were elevated fallow lands in secluded areas. The female turtle laid all the mature eggs at a time for each clutch at night. A gravid female turtle laid two clutches of eggs in each breeding season and the mean clutch size was $9.7 \pm 1.5$ eggs and mean weight of each egg was 8.9 $\pm 1.3 \mathrm{~g}$. The eggs are elongated in shape and whitish in colour. The mean incubation period was $119 \pm 30$ days. The incubation period of first clutch was the longer than the second clutch. The hatchlings emerged out between April and May. Hatchery success was found $56.8 \%$. The percentage of weight gain and specific growth rate (SGR) by weight of hatchlings in the first year was greater than second and third year. Present investigation was made to explore the possibility to raise turtle farming in captive condition.
\end{abstract}

Key words: Breeding biology, Bengal eyed turtle, clutch size, incubation, hatching success.

\section{INTRODUCTION}

Freshwater turtles are consumed by a group of people as a source of protein and for its delicacy (Rao and Singh 1987). Turtle population is declining due to over exploitation and habitat destruction (Rao 1986). The turtle species is very rare and collected for food (Zhao and Adler 1993). The declination rate of the species is serious in the past decade, may face extinction in future in the wild (Sandra and Daniela 2000). As turtle meat and turtle products are very delicious, its demand is increasing progressively. Further, turtle being an ancillary exportable commodity, Bangladesh exported 3164.24 metric tons of freshwater turtles in fiscal year 1980-2002 (Anon 2002).

Bangladesh is a signatory of the CITES, however, some of the turtle species are still indiscriminately being killed for local consumption. Unsustainable exploitation is a great threat to extinction in near future (Sarker and Hossain 1997). Once turtle species were very prevalent in different ecoclimatic conditions of Bangladesh (Rashid and Swingland 1997). However, in the last few decades, due to over exploitation, random hunting, unlawful catching, habitat, breeding ground destruction, etc., the population has been decreasing rapidly (Sarker and Hossain 1995).

${ }^{1}$ Author for correspondence: Department of Zoology, Dhaka College, Dhaka-1205, Bangladesh. $<$ drlokmanhossain@yahoo.com>. 
Breeding in hatchery condition could be an appropriate solution to replenish the natural population of turtle (Hossain and Sarker 1995). By far, a little information is available on breeding biology of Morenia petersi in country. Some works have, however, been done in other countries on the distribution and biology by Duda and Gupta (1978), Vijaya (1981), Yadava and Prashad (1982), Fugler (1984), Bhupathy and Vijayan (1989), Iverson (1992), Grey et al. (1993), Janzen (1993), Passmore and Ronald (1993), Raju and Patel (1993), Shrestha (1997), Romulus and Whitaker (1997) and Whitaker and Andrews (1997). Therefore, it is felt that artificial breeding in the hatchery could be appropriate steps to cater the market demands. In view of the importance of this species, the present work was undertaken to study some biological aspects especially on the breeding of $M$. petersi.

\section{MATERIAL AND METHODS}

A study on breeding biology of Morenia petersi was undertaken in nature and in captivity between January 1997 and December 2001 in different ecoclimate zone of Bangladesh. A number of breeding parameters were studied, that is, breeding season, breeding ground, nest building, nesting, egg laying, clutch size, incubation period, hatching, predation, growth of hatchling, etc.

Breeding season was determined by monitoring the breeding activities in nature as well as in captivity. Local people were interviewed for information on the breeding season. Information was also collected through questionnaires from the catchers in the study areas. A total of 24 specimens of gravid M. petersi were collected from the nature and reared in special purpose built enclosures at the zoological garden of the University of Dhaka as well as at mini turtle hatchery in Arua Union, under Manikgonj district for observing the breeding activities in captivity. The maturity of eggs of the turtle species was ascertained by pressing the fingers through the folds of hind limbs of the turtle. The nesting activity was closely observed at day and night. A good number of nesting sites and nests were observed in nature. A total 66 specimens of $M$. petersi were dissected throughout the study period in the field and in laboratory to observe the gonad development, eggs maturity, eggs number to detect the egg laying period and clatch size.

The clutch size was determined by monitoring nests in nature and in captivity. Egg counting was done by dissecting the female turtles in the field, local turtle markets and in the laboratory. The presence or absence of mature and immature eggs in both oviducts helped determine clutch size. The first egg laying period or first clutch was defined by the presence of mature and immature eggs; the second egg laying period was ascertained when no immature 
eggs other than mature eggs were in both the oviducts. Electric balance and vernier calipers were used to measure weight, length, girth and dimension of eggs.

The incubation period was calculated from the day of keeping the eggs underneath the soil. Loam, sandy loam, clay, silt clay soil were used in the trays and breeding grounds to study the incubation and hatching performances. Temperature and moisture were recorded by using soil thermometer and spot tester regularly. Hatching success was calculated by enumerating the number of hatchlings in relation to the eggs laid per clutch.

\section{RESULTS AND DISCUSSION}

Egg laying: The breeding season of $M$. petersi was in winter months between November and February. Female turtles laid two clutches of eggs in a breeding season each year. First clutch of eggs laid between November and December and second clutch mid January and February. Both the oviducts were developed and contained mature and immature eggs in the beginning of November. There was no mature egg in the oviducts during the non-breeding season.

The present study showed that the breeding season of $M$. petersi was between November and February in a year. Das (1995) and Fugler (1984) stated that the breeding season of the turtle was in winter months, Hossain and Sarker (1993) mentioned November to January; Rashid and Swingland (1997) stated end of December and January. Whitaker and Andrews (1997) reported the turtle nests only in April to May, whereas Auffenberg (1981) mentioned that the egg laying period was late summer in India.

Nesting sites: Nesting sites of $M$. petersi were in the elevated portion of fallow lands. They used the grass lands along village roads, bank of ponds and canals, erected portion of pea seed land, vegetable garden, fallow lands of school yard, corners of enclosure, rim of the mini ponds and cemented tank in the animal garden for nesting. Nests were dug in loam soil with sparse vegetation in secluded areas. The nesting sites were in loam soil (75\%), sandy soil $(18.75 \%)$ and clay soil (6.25\%). The nesting sites were located at a distance of $8 \mathrm{~m}$ to 720 $\mathrm{m}(172.6 \pm 197 \mathrm{~m})$ from water and at a height of $3.4 \mathrm{~m}$ to $7.2 \mathrm{~m}$ above the surface $(n=16)$ of water.

It was noticed that only female turtles selected the nesting sites at night. There was no evidence to sharing the male for nesting. A female turtle was found in making nest on the bank of a pond in the village Razargaon, Hajigang upazila at 22:20 hrs on 23 November; another nest was making at 21:45 hrs in the village Shaskipara, Chandpur, on 18 November; a female was found nesting at the side of village road, Naogaon, Matlab at 21:15 hrs on 21 February. 
Vegetation around the nests: In the present study it was found that most of the nests were made by the turtle in fellow lands in secluded areas with spare vegetation. Some of the vegetation i.e. Cynodon dactylon (Durba), Clerodendron infortuntum (Bhat), Solanum torvum (Titbegun), Mentha viridis (Pudina), Centella asiatica (Thankuni patha), Foeniculum vulgare (Mouri), Vernonia cineria (Shealmutra), Ghora catla, Assam lata, Dhansha, Cazanus cajan (Arahar dal), etc. were recorded in and around the nests of this turtle species.

Nest Building: In nature, nests were made in hard ground $(\mathrm{n}=9)$ with the help of sharp claws of fore limbs and the head. The soil of nesting ground was loam and moist. Female turtles concealed their eggs in the nests and then labeled the soil on the nests with the help of limbs, head, neck, and the plastron to mislead the predators. In captive condition, 17 to 19 minutes $(20 \pm 2.9)$ were required to build nests for egg laying. In nursery ground of Aura union, Manikganj a $M$. petersi made nest on $16^{\text {th }}$ February within 19 minutes and released 9 eggs. The eggs were hidden in the nest with the help of hind limbs.

Nest depth and diameter: In nature, the nests were found as pitcher shaped in hard soil $(n=12)$ and vat like structure in the loose soil $(n=5)$. The mean depth of nest was $7.8 \pm 0.4 \mathrm{~cm}$ with a variation from $7.2 \mathrm{~cm}$ to $8.4 \mathrm{~cm}$, and the diameter was $9.4 \pm 0.5 \mathrm{~cm}$ with a variation from $8.5 \mathrm{~cm}$ to $10.6 \mathrm{~cm}$ (Table 1). It was observed that the greater the clutch size higher the diameter and lower the depth of the nest (Fig 1). Clutch size in the nests varied from 7 to 13 eggs $(9.7 \pm$ 1.5) as shown in Table 1.

Table 1. Measurement of nests of Bengal eyed turtle Morenia petersi.

\begin{tabular}{|c|c|c|c|c|c|}
\hline $\begin{array}{l}\text { Nest diameter } \\
\text { (cm) }\end{array}$ & Mean \pm SD & $\begin{array}{l}\text { Depth } \\
(\mathrm{cm})\end{array}$ & Mean \pm SD & Clutch size & Mean \pm SD \\
\hline 10.6 & & 7.2 & & 13 & \\
\hline 10.3 & & 7.3 & & 12 & \\
\hline 9.9 & & 7.3 & & 11 & \\
\hline 9.9 & & 7.4 & & 11 & \\
\hline 9.7 & & 7.4 & & 10 & \\
\hline 9.7 & & 7.4 & & 10 & \\
\hline 9.4 & & 7.5 & & 10 & \\
\hline 9.3 & $9.4 \pm 0.5$ & 7.5 & $7.8 \pm 0.4$ & 10 & $9.7 \pm 1.5$ \\
\hline 9.3 & & 7.5 & & 9 & \\
\hline 9.3 & & 7.7 & & 9 & \\
\hline 9.3 & & 7.9 & & 9 & \\
\hline 9.3 & & 8.0 & & 9 & \\
\hline 9.2 & & 8.1 & & 9 & \\
\hline 9.1 & & 8.0 & & 8 & \\
\hline 9.1 & & 8.2 & & 7 & \\
\hline 8.5 & & 8.4 & & 8 & \\
\hline
\end{tabular}


The relationship between the nest diameter and nest depth was negatively correlated $(\mathrm{r}=-0.852, \mathrm{n}=16)$ and the relation was not significant $(\mathrm{t}=1.43, \mathrm{df}=$ 15 and $\mathrm{p}<0.05)$. The relationship of nest diameter and clutch size was significantly correlated $(r=0.920, t=20.34$ and $\mathrm{p}<0.01)$ and the nest depth and clutch size was negatively correlated but not significant $(\mathrm{r}=-0.855, \mathrm{t}=$ 1.42 , and $\mathrm{p}<0.05)$. The regression line of nest diameter and clutch size was highly correlated $\left(\mathrm{Y}=0.3039 \mathrm{x}+6.5499, \mathrm{R}^{2}=0.8457\right)$ and the nest depth and clutch size $\left(\mathrm{Y}=-0.2067 \mathrm{x}+9.6774, \mathrm{R}^{2}=0.7314\right)$ was less correlated. That means $84.6 \%$ clutch size values can be explained $(\mathrm{Y})$ by the values of nest diameter $(\mathrm{X})$ and on the other hand $73.1 \%$ by the values of nest depth (X) (Fig. 1).

\section{O Nest diameter $*$ Nest depth}

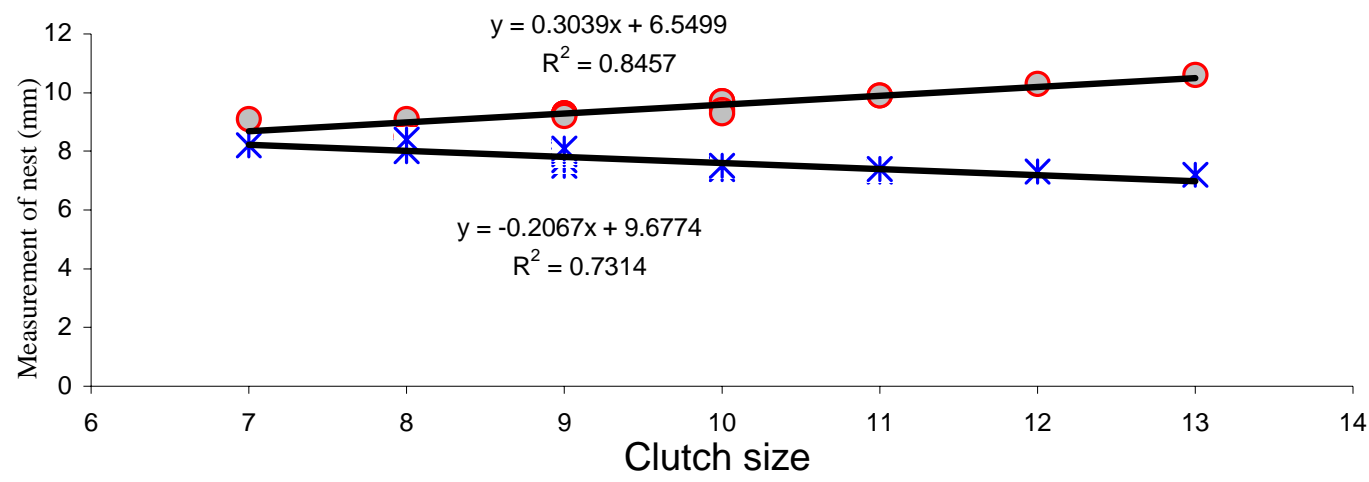

Fig. 1. Regression on clutch size with the depth and diameter of the nest of Morenia petersi.

Egg laying sequence and period: In nature, the female $M$. petersi laid all mature eggs at a time in the nest. It was noted that the egg laying time was at night within $20: 00 \mathrm{hrs}$ to $23: 00 \mathrm{hrs}(\mathrm{n}=12)$. In captivity, one female turtle laid 13 eggs at $21: 50 \mathrm{hrs}$ on $5^{\text {th }}$ December; another turtle laid nine eggs in an earthen jar on $10^{\text {th }}$ February at 22:30 hrs. A female turtle laid 10 eggs in the nursery bed at 23:00 hrs on 25 th February, and another one laid 10 eggs at 22:00 hrs on $13^{\text {th }}$ November in a cell of serpentarium of the zoological garden. Four gravid turtles were released in zoological garden. Of them, one turtle laid nine eggs in the water of earthen jar on $3^{\text {rd }}$ December, the rest three turtles made nest at the corner of the enclosure and on the bank of mini ponds and, laid 10 eggs, 11 eggs and 9 eggs on $13^{\text {th }}, 17^{\text {th }}$ and $18^{\text {th }}$ November for the first time as first clutch. Afterwards, one laid 10 eggs on $15^{\text {th }}$ February rest turtles were laid 9 eggs on $16^{\text {th }}$ February and 9 eggs on $10^{\text {th }}$ February at the corner of 
the mini ponds and enclosure in the zoological garden for the second time. It was concluded that the female $M$. petersi started laying first clutch of eggs from November and second clutch in mid February in a breeding season.

There were no mature egg in the oviducts of dissected turtles just after laying the first clutch, except some immature ones $(n=17)$ but after laying the second clutch there were no mature and immature eggs in the oviducts $(n=15)$ which suggests that ovulation time or egg laying time in this species was November to February.

Clutch size: In nature, the clutch size varied from 7 to 13 eggs $(9.7 \pm 1.5)$. The clutch size was higher in the first clutch than the second. A total of 66 female gravid turtles were dissected in different trade centers and local markets both dead and alive condition during the breeding season. It was noted that the clutch size varied between 5 and 15 eggs $(8.5 \pm 0.7)$.

The weight of dissected turtles varied from 420 to $720 \mathrm{~g}(571.7 \pm 35.1)$. Though the body weight and clutch size were correlated, the value was not significant $(r=0.499, t=1.41$ and $p<0.05)$, as suggests that some of the bigger turtles contained smaller clutch size.

Table 2. Clutch size of Bengal Eyed Turtle, Morenia petersi determined by dissection.

\begin{tabular}{lcccccc}
\hline $\begin{array}{l}\text { No. of } \\
\text { sample }\end{array}$ & $\begin{array}{l}\text { Mean. weight } \\
\text { turtles (g) }\end{array}$ & $\begin{array}{c}\text { Total } \\
\text { eggs } \\
\text { found }\end{array}$ & Range (eggs) & $\begin{array}{c}\text { Mean } \pm \text { SD } \\
\text { (clutch size) }\end{array}$ & $\begin{array}{c}\text { Relationship } \\
\text { (weight \& } \\
\text { clutch size) }(\mathrm{r})\end{array}$ & $\begin{array}{c}\text { 't- statistic" } \\
\text { calculated } \\
\text { value }\end{array}$ \\
\hline 07 & $507.8 \pm 61.1$ & 53 & $5-13$ & $7.6 \pm 2.8$ & 0.666 & $1.99=$ \\
13 & $600.0 \pm 65.4$ & 105 & $5-11$ & $8.1 \pm 1.6$ & 0.840 & $0.28=$ \\
04 & $583.8 \pm 27.5$ & 35 & $7-10$ & $8.8 \pm 13$. & $0-.927$ & $0.36=$ \\
12 & $619.2 \pm 74.3$ & 103 & $6-15$ & $8.6 \pm 2.3$ & 0.511 & $1.88=$ \\
09 & $556.7 \pm 56.6$ & 78 & $7-11$ & $8.7 \pm 1.3$ & 0.568 & $2.22=$ \\
03 & $566.7 \pm 37.9$ & 25 & $8-9$ & $8.3 \pm 0.6$ & $0-.381$ & $0.58=$ \\
05 & $586.0 \pm 25.1$ & 41 & $7-9$ & $8.2 \pm 0.8$ & 0.762 & $2.04=$ \\
10 & $523.0 \pm 58.9$ & 85 & $7-10$ & $8.5 \pm 1.1$ & $0-.096$ & $2.73 *$ \\
04 & $602.5 \pm 38.6$ & 34 & $7-10$ & $8.5 \pm 1.3$ & 0.836 & $2.16=$ \\
\hline
\end{tabular}

$=$ Significant at $5 \%$ level and $==$ Insignificant

During the present study it was found that $M$. petersi laid two clutches of eggs in a breeding season of each year and clutch size was 7 to 13 eggs (mean $9.7 \pm 1.5$ ). Rashid and Swingland (1997) mentioned that multiple clutches has not been confirmed. Fugler (1984) mentioned that the clutch size was 2 to 7 eggs and Whitaker and Andrews (1997) mentioned as only 2 eggs .On the basis of dissection of 66 female, clutch size was determined 5 to 15 eggs during the present study. 
Shape and colour of eggs: The eggs of $M$. petersi were elongated shape. The longish and almost oval eggs slightly tapered in one end and the other anterior end was slightly pointed. The shell was delicate in nature, fine in texture and slightly glossy in appearance. The colour of fresh eggs was usually whitish, sometimes brownish. The colour became pale in the later part of incubation when embryos became mature inside the eggs.

Weight of eggs: The weight of individual egg varied from $6.0 \mathrm{~g}$ to $11.3 \mathrm{~g}$ (mean $8.9 \pm 1.3 \mathrm{~g})(\mathrm{n}=100)$. Maximum eggs of $M$. petersi were within the weight of 9.1 $\mathrm{g}$ to $10 \mathrm{~g}(\mathrm{n}=32)$. During the present study it was found that the mean weight of eggs was $8.9 \pm 1.3 \mathrm{~g}$ (range $6.0 \mathrm{~g}-11.3 \mathrm{~g}$ ), girth of eggs $21.6 \pm 1.4 \mathrm{~mm}$ (range $18.6 \mathrm{~mm}-24.3 \mathrm{~mm}$ ) and that of length $33.3 \pm 1.6 \mathrm{~mm}$ (range $30.1 \mathrm{~mm}-37.1$ $\mathrm{mm})$. But Whitaker and Andrews (1997) reported that the mean weight of eggs was $10.3 \pm 0.03 \mathrm{~g}$, girth $20.2 \pm 0.2 \mathrm{~mm}$ and length $49.5 \pm 0.22 \mathrm{~mm}$.

Diameter: The longest axis of eggs of $M$. petersi varied from $30.1 \mathrm{~mm}$ to 37.1 $\mathrm{mm}$ (mean $33.3 \pm 1.6 \mathrm{~mm}$ ) and the girth was $18.6 \mathrm{~mm}$ to $24.3 \mathrm{~mm}$ (mean $21.6 \pm$ $1.4 \mathrm{~mm}$ ). The dimension of 100 eggs was $33.3 \times 21.6 \mathrm{~mm}$. The dimension of the eggs increased when the weight of eggs were increased. It was inferred that the eggs, which laid at a time, were not similar size and weight (Table 3). The relationship between the eggs weight and length of eggs was highly correlated $(\mathrm{r}$ $=0.71, \mathrm{n}=100, \mathrm{t}=14.12$ and $\mathrm{p}<0.01)$. The weight and girth of eggs was also significantly corrected $(r=0.74, t=16.4$ and $p<0.01)$ and the length and girth was statistically significant $\mathrm{r}=0.52, \mathrm{t}=7.07$ and $\mathrm{p}<0.01$ ).

Table 3. Measurement of eggs of Bengal Eyed Turtle Morenia petersi .

\begin{tabular}{rcccccc}
\hline \multirow{2}{*}{$\begin{array}{c}\text { Clutch } \\
\text { size }\end{array}$} & \multicolumn{2}{c}{ Weight $(\mathrm{g})$} & \multicolumn{2}{c}{ Length $(\mathrm{mm})$} & \multicolumn{2}{c}{ Girth $(\mathrm{mm})$} \\
\cline { 2 - 7 } & Range & Mean $\pm \mathrm{SD}$ & Range & Mean \pm SD & Range & Mean $\pm \mathrm{SD}$ \\
\hline 12 & $6.3-10.9$ & $8.8 \pm 1.2$ & $30.3-36.1$ & $33.5 \pm 1.5$ & $18.8-22.3$ & $20.9 \pm 1.0$ \\
9 & $7.6-10.8$ & $9.3 \pm 1.1$ & $31.6-36.2$ & $33.3 \pm 1.5$ & $20.1-23.2$ & $21.7 \pm 1.1$ \\
11 & $7.3-10.2$ & $8.5 \pm 1.1$ & $30.1-35.2$ & $32.0 \pm 1.5$ & $20.3-24.2$ & $21.8 \pm 1.5$ \\
13 & $6.2-10.8$ & $8.4 \pm 1.5$ & $31.4-34.8$ & $33.0 \pm 1.1$ & $18.6-23.2$ & $21.0 \pm 1.5$ \\
11 & $7.3-10.4$ & $8.9 \pm 1.0$ & $31.4-37.1$ & $33.4 \pm 1.8$ & $20.4-24.3$ & $21.9 \pm 1.2$ \\
9 & $7.3-11.3$ & $9.5 \pm 1.3$ & $31.5-36.9$ & $34.3 \pm 1.8$ & $20.7-23.6$ & $22.2 \pm 1.1$ \\
10 & $6.8-10.9$ & $9.4 \pm 1.5$ & $31.8-34.8$ & $33.9 \pm 1.8$ & $18.9-23.2$ & $21.6 \pm 1.3$ \\
12 & $7.7-11.2$ & $9.0 \pm 1.1$ & $30.3-35.5$ & $33.1 \pm 1.6$ & $18.7-24.1$ & $21.9 \pm 1.6$ \\
13 & $6.0-10.0$ & $8.4 \pm 1.2$ & $31.2-36.2$ & $33.2 \pm 1.3$ & $19.0-23.2$ & $21.7 \pm 1.3$ \\
\hline
\end{tabular}

Moreover, the linear regression between the weight and length of eggs was correlated $\left(\mathrm{Y}=1.1595 \mathrm{x}+22.967\right.$ and $\left.\mathrm{R}^{2}=0.6012\right)$ and weight and girth was also correlated $\left(\mathrm{Y}=0.1702 \mathrm{x}+20.118\right.$ and $\left.\mathrm{R}^{2}=0.0292\right)$ (Fig. 2). That means $60.1 \%$ weight variation $(\mathrm{Y})$ can be explained by the values of length $(\mathrm{X})$, on the other hand $2.9 \%$ of weight values $(\mathrm{Y})$ can be explained by the values of the girth of eggs $(\mathrm{X})$. 
- Egg length $\quad$ Girth of eggs

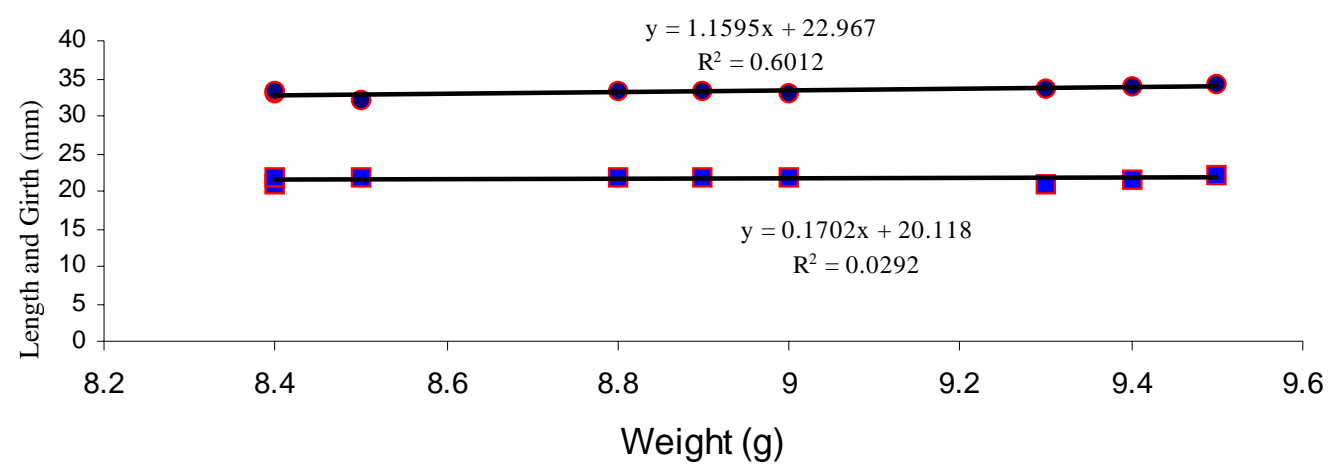

Fig. 2. Regression on weight with length and girth of eggs of Morenia petersi.

Incubation period: The incubation period varied between 76 and 148 days and mean was $119.1 \pm 30.3$. The incubation period was longer for the first clutch of eggs than the second. The period for the first clutch ranged from 130 to 148 days $(141.5 \pm 4.8)$ and second clutch from 76 to 90 days $(81.7 \pm 4.8)$. The factors are noted involved to maintain the incubation period were temperature, humidity, nest depth, soil quality, shade etc. The incubation period was longer when temperature was low and incubation period was short when temperature and humidity was optimum. The depth of nest was also correlated to the incubation period.

Temperature of nests: The mean temperature of nest varied between $27.5^{\circ} \mathrm{C}$ and $30.0^{\circ} \mathrm{C}(28.9 \pm 1.1)$. The temperature varied due to heavy rainfall and droughts during the incubation period. Optimum temperature ensured the minimum incubation period. First clutch of eggs hatched within longer period with minimum temperature.

Humidity of breeding ground: The range of mean humidity in the nest of $M$. petersi was $72 \%$ to $95 \%$ (mean $82.3 \pm 6.9 \%$ ) during the incubation period. The second clutch of eggs hatched out within short period of time in comparison to first clutch of eggs (Table 4).

Soil quality of nests: Some experimental study revealed that hatching success influenced by soil texture in some extends i.e. loam, sandy loam and clay characteristics. Most of the hatchlings were found in loam soil with partial shady place. The hatching percentage was $86 \%$ in loam soil, $10 \%$ in sandy soil and $4 \%$ in clay soil. It was found that most of the eggs dried in sandy soil and that formed vacuum in the eggshell. As a result, hatching percentage was low in sandy clay soil in comparison with loam soil. The eggs were tighten by wet clay soil in sunny days. 


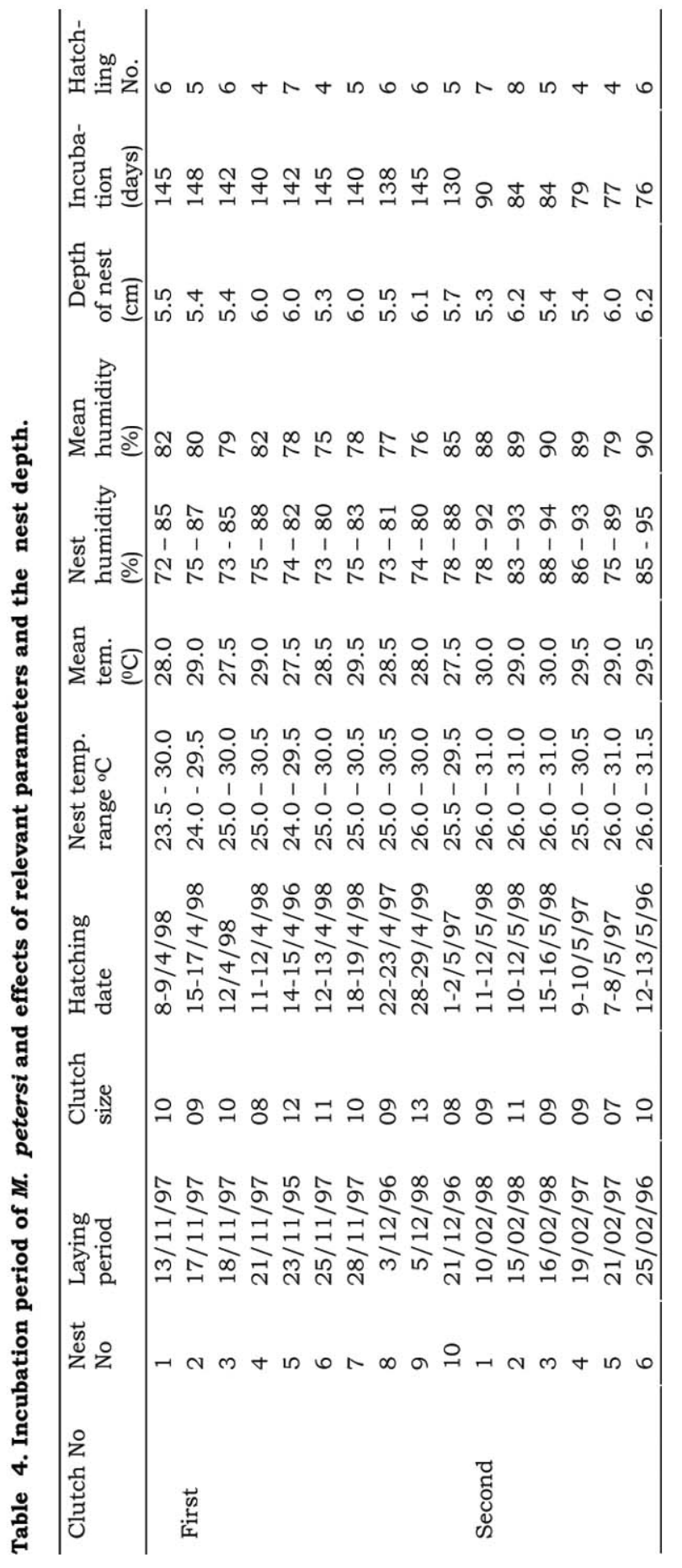




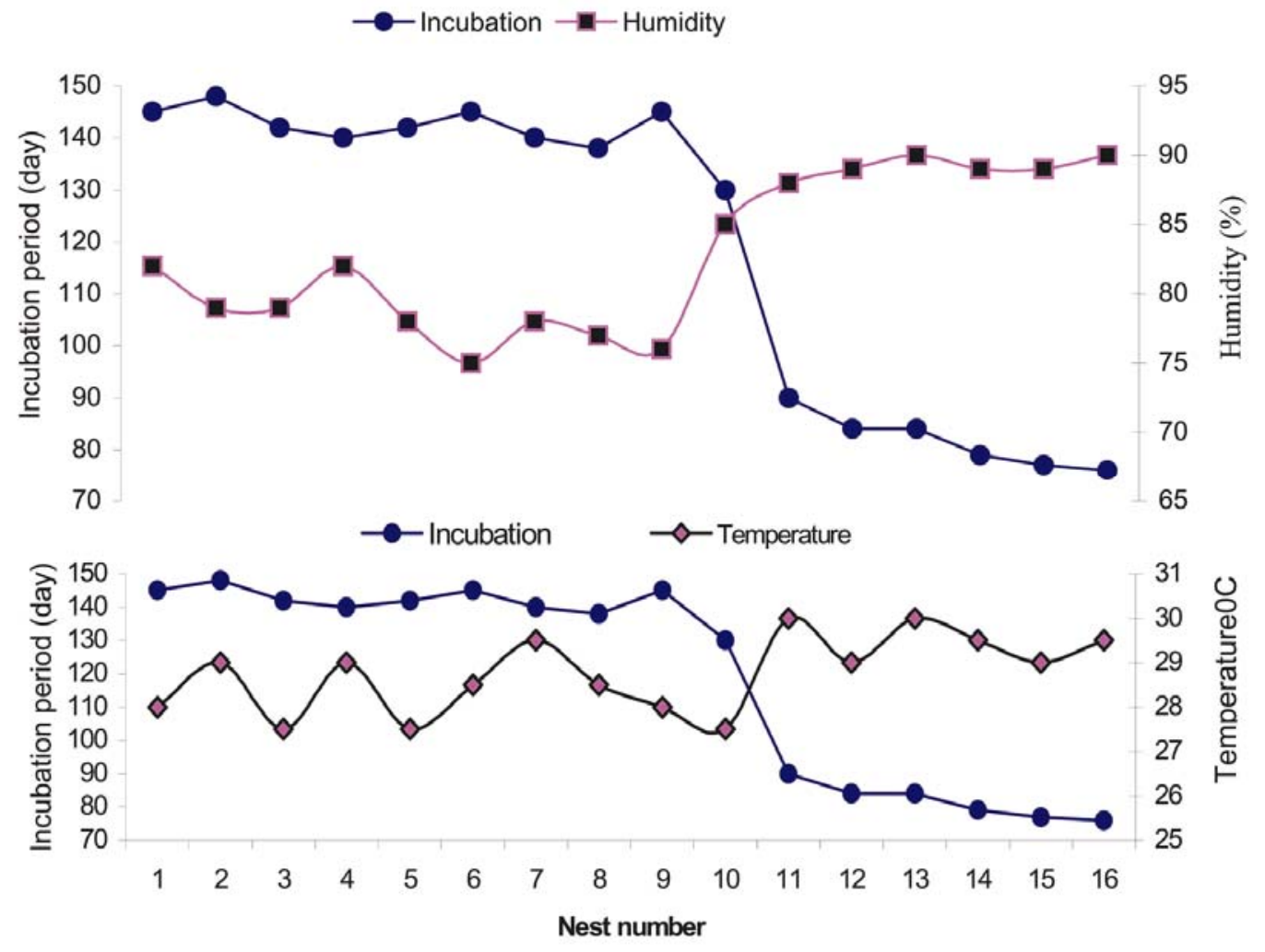

Fig. 3. Incubation period of eggs of Morenia petersi and environmental parameters of nests.

Moisture of the nests: In captivity, some eggs were kept underneath the soil of hatching trays where sunlight penetrated directly. The eggs were not hatch but the yolk and albumen became dry and the colour of shell became pale. In addition, some eggs did spoil due to water staging in the nesting ground.

Hatching in successive months: A total of 88 hatchlings emerged out from 155 eggs, which were taken from the nests. Of the hatchlings, $49(55.7 \%)$ were hatched in April 39 (44.3\%) in May. The hatching success was 31.6\% in April and $25.2 \%$ in May in relation to eggs laid.

Hatching success: The hatching success was $56.8 \%$ in relation to total eggs laid (Table 5). There was no clutch of eggs produced $100 \%$ young but $43.2 \%$ of eggs did not produced any young.

Breeding success: The total number of eggs laid and the nestlings emerged out from the nests were recorded. One hundred and fifty five eggs of 16 clutches were kept under the ground and 88 nestlings were hatched. The hatching success was $56.8 \%$ in relation to the eggs laid and total young hatched. Some 
nestlings were lost due to handling, fungal infection, predation and other incidents .So the hatchery success was $38.7 \%$ in relation to the hatchlings that came out and escaped from predation.

Table 5. Percentage of hatching eggs of Morenia petersi in successive months.

\begin{tabular}{|c|c|c|c|c|c|}
\hline $\begin{array}{l}\text { Hatching } \\
\text { time }\end{array}$ & $\begin{array}{l}\text { Eggs } \\
\text { laid }\end{array}$ & $\begin{array}{c}\text { Young } \\
\text { hatched }\end{array}$ & $\begin{array}{c}\text { Relation to total } \\
\text { young hatched } \\
(\%)\end{array}$ & $\begin{array}{c}\text { Hatching } \\
\text { success, relation } \\
\text { to eggs laid (\%) }\end{array}$ & $\begin{array}{l}\text { Hatching success } \\
\text { relation to eggs } \\
\text { hatched }(\%) \\
\end{array}$ \\
\hline \multirow{9}{*}{ April } & 12 & 7 & \multirow{9}{*}{31.6} & 58.3 & \multirow{9}{*}{55.7} \\
\hline & 9 & 6 & & 66.7 & \\
\hline & 13 & 6 & & 46.2 & \\
\hline & 10 & 5 & & 50.0 & \\
\hline & 9 & 5 & & 55.6 & \\
\hline & 10 & 6 & & 60.0 & \\
\hline & 10 & 6 & & 60.0 & \\
\hline & 8 & 4 & & 50.0 & \\
\hline & 11 & 4 & & 36.4 & \\
\hline \multirow{7}{*}{ May } & 8 & 5 & \multirow{7}{*}{25.2} & 62.5 & \multirow{7}{*}{44.3} \\
\hline & 7 & 4 & & 57.1 & \\
\hline & 10 & 6 & & 60.0 & \\
\hline & 11 & 8 & & 72.7 & \\
\hline & 9 & 5 & & 55.6 & \\
\hline & 9 & 7 & & 77.8 & \\
\hline & 9 & 4 & & 44.4 & \\
\hline
\end{tabular}

Predation: Monitor lizards, mongooses, crows, kites, red ants were noted as the major predators for the eggs and hatchlings of $M$. petersi. During the study period 10 nestlings and 81 eggs were preyed by these predators from the nesting grounds. In view of increasing demand, the artificial breeding of $M$. petersi in captivity should be practised to meet the market demand and to reduce the pressure on the natural population. Bangladesh has a vast inland having open and closed freshwater sources where this species could thrive. The present study revealed that this biological information could be used in successful breeding of the species in controlled conditions. Further detailed study and initiation of turtle (M. petersi) farming may be undertaken simultaneously.

\section{LITERATURE CITED}

ANON, 1992-2002. Export from Bangladesh, Export Promotion Bureau of Bangladesh 122-124 Motijheel C/A, Dhaka.

AUFFENBERG, W. 1981. Behaviour of Morenia petersi (Reptilia, Testudinata, Trionychidae) in a drying lake in Rajasthan, India. J. Bombay Nat. Hist. Soc. 78(3): 487-493.

BHUPATHY, S. and VIJAYAN, V. S. 1989. Predation on the Indian Flapshell Turtle, Morenia petersi, in Keoladeo National Park, Bharatpura, Rasthan. Proc. Nat, Symp. anim. Behav. PP Institute of Sci. Bhavnagar. 27 - 33.

DAS, I. 1995. Turtles and Tortoises of India. Oxford University Press, Bombay, 176+xpp.

DUDA, P. L. and GUPTA, V. K. 1978. Intra-abdominal retention of eggs by the Softshell Turtles, Morenia petersi. Herp., Review 9(2) : 46. 
FUGLER, C. M. 1984. The commercially exploited Chelonia of Bangladesh. Taxonomy, Ecology, Reproductive biology and Ontogeny. Bangladesh Fish. Inf. Bull. 2(1): 1- 52.

GRAY, P. C., MILLER, K. and PACKARD, M. J. 1993. Environmentally induced variation in body size of turtle hatchlings in natural nests. (Dept. Biol. Colorado State Univ. Fort, Collins Co. 80523) Oecologia 93(3): 445-448.

HOSSAIN, M. L. and SARKER, S. U. 1993. Freshwater turtles of Bangladesh. Bangla Academy Biggan Patrica, Dhaka. 20(1): 109-120.

HOSSAIN, M. L. and SARKER, S. U. 1995. Reproductive biology of Indian roofed turtle, Kachuga tecta in Bangladesh. J. Chelonian Conservation and Biology. Int. Bull. Chelonian Research, Lunenburg, USA. 1(3): 226-227.

IVERSON, J. B. 1992. Correlates of reproductive output in turtles (Order Testudines) Herpetological Monographs 6: 25-42.

JANZEN, F. J. C. 1993. The influence of incubation temperature and family on eggs embryo and hatchlings of the Smooth soft shell turtle. Physiol. Zool., Population Biology, Univ. California 2320, Storer Hall Davisca (95616 USA). 66(3): 349-373.

PASSMORE, H. L. and RONALD, J.B. 1993. Effects of geographic origin and incubation temperature on hatchling Snapping turtles, Chelydra serpentina: Implications for turtle conservation practice across the species, range. Department of Zoology, University of Guelph, Ontario, Canada NIG 2 W1. 195 202pp.

RAJU, V. and PATEL, B. H. 1993. Captive breeding of the Indian Roofed Terrapin, Kachuga tecta (Gray) J. Bombay Nat. Hist. Soc. 90(1) : 109 - 112.

RAO, R. J. 1986. Freshwater turtle conservation in National Chambal Sanctuary, Tigerpaper. 13(3): 28-29.

RAO, R. J. and SINGH, L. A. K. 1987. Notes on the ecological relationship in basking and nesting site utilization among Kachuga spp. (Reptilia: Chelonia) in National Sambal Sanctuary. J. Bombay Nat. Hist. Soc. 84(3): 599-604.

RASHID, S. M. A. and SWINGLAND, I. R. 1997. On the ecology of some freshwater turtles in Bangladesh Proc. Conservation Restoration and Management of tortoise and turtles. An Int. Conf. Turtle and Tortoise Society, pp. 225-242.

ROMULUS and WHITAKER, R. 1997. Turtle rearing in village pond. Proc. Conservation, Restoration, and Management of Tortoises and Turtles, USA, pp.106-108.

SANDRA, A. and DANIELA, F. 2000. Asian turtles are threatened by extinction. Turtle and Tortoise. Newsletter, (The Newsletter of Chelonian Conservationists and Biologists), By Chelonian Res. Foundation 1: 1-9.

SARKER, S. U. and HOSSAIN, M. L. 1995. Population, Ecobiological Status, Captive Propagation and Conservation Problems of Morenia petersi in Bangladesh. International congress of chelonian conservation, France (Proc). pp 43-46.

SARKER, S. U. and HOSSAIN, M. L. 1997. Population and habitat status of freshwater turtles and tortoises of Bangladesh and their conservation aspect. Proc. Conservation, Restoration, and Management. USA. pp. 290-294.

SHRESTHA, T. K. 1997. Status, Biology, Conservation and Management of Tortoises and Turtles in the Himalayan Foothills of Nepal, Proc. Conservation, Restoration, and Management of Tortoises and Turtles, Lunenburg, USA. pp. 278-286.

VIJAYA, J. 1981. Successful Artificial Breeding of Morenia petersi Granosa (Smith) J. Bombay Nat. Hist. Soc. 79: 210-211. 
WHITAKER, R. and ANDREWS, H. V. 1997. Captive Breeding of Indian Turtles and Tortoises at the center for Herpetology, Madras Crocodile Bank. Proc. Conservation Management of Tortoises and Turtles. An Int. Conf. New York Turtle and Tortoise Soc. pp. 166-170.

YADAVA, M. R. and PRASHAD, B. 1982. Observations on the breeding biology of Indian Ttropical Pond Turtle, Morenia petersi Granosa (Sheoepff). Indian J. Zool. 23(1): 51-56.

ZHAO, E. and ADLER, K. 1993. Asian Turtle Trade. Herpetology of China. Society for the study of Amphibians and Reptiles. Oxford, Ohio. pp. 1-16.

(Manuscript received on 15 September, 2014; revised on 16 September, 2014) 